\title{
Effect of replacing oat fodder with fresh and chopped oak leaves on in vitro rumen fermentation, digestibility and metabolizable energy
}

\author{
K. Rajkumar, R. Bhar, A. Kannan, R.V. Jadhav, Birbal Singh and G. Mal
}

Animal Nutrition Laboratory, Indian Veterinary Research Institute, Regional Station, Palampur, Himachal Pradesh, India. Corresponding author: K. Rajkumar, e-mail: rajkumar_1509@rediffmail.com, RB: rbharplp@gmail.com, AK: akanna72@gmail.com, RJ: drravindravilas@gmail.com, BS: bshpalampur@yahoo.co.in, GM: gorakh14@yahoo.com Received: 13-03-2015, Revised: 19-07-2015, Accepted: 27-07-2015, Published online: 26-08-2015

doi: 10.14202/vetworld.2015.1021-1026 How to cite this article: Rajkumar K, Bhar R, Kannan A, Jadhav RV, SinghB, Mal G (2015) Effect of replacing oat fodder with fresh and chopped oak leaves on in vitro rumen fermentation, digestibility and metabolizable energy, Veterinary World 8(8): 1021-1026.

\begin{abstract}
Aim: A study was conducted to evaluate the effect of replacing oat fodder (OF) with fresh oak leaves (FOL) or chopped oak leaves (COL) on rumen fermentation and digestibility through in vitro gas production technique (IVGPT).

Materials and Methods: Nine different diets were prepared by mixing OF with oak leaves (either FOL or COL) in different ratios $(100: 0,75: 25,50: 50,25: 75$, and 0:100). The rations were evaluated through Hohenheim IVGPT with $200 \mathrm{mg}$ substrate and $30 \mathrm{ml}$ of buffered rumen liquor. All the syringes were incubated at $39^{\circ} \mathrm{C}$ for $24 \mathrm{~h}$ in buffered rumen liquor of cattle. After $24 \mathrm{~h}$, the total gas production was recorded, and the contents were analyzed for in vitro methane production, protozoa no. and ammonia-N.

Results: Chopping $(\mathrm{p}<0.01)$ reduced the tannin fractions as well as non-tannin phenol. Increase in levels of oak decreased total gas production, methane, organic matter (OM) digestibility, and metabolizable energy (ME) values. The polyphenol content of the substrate did not show any significant difference on the protozoal count.

Conclusion: In vitro studies revealed that the addition of oak leaves reduced the methane production and ammonia nitrogen levels; however, it also decreased the OM digestibility and ME values linearly as the level of the oak leaves increased in the diet. Chopping was effective only at lower inclusion levels. Further studies, especially in vivo studies, are needed to explore the safe inclusion levels of oak leaves in the diet of ruminants.
\end{abstract}

Keywords: chopping, in-vitro, methane, oak leaves, oat fodder.

\section{Introduction}

Availability of fodder among Asian countries particularly with countries like India is not adequate to meet the ever growing livestock population. There is a great need to explore new feed resources to meet this deficit without competing with food chain [1]. Tree fodders are the alternate source of small ruminant feeds to that of conventional green fodders which have the potential to mitigate the gap between demand and supply of feeds [2]. Tree fodders have similar nutritive value as that of leguminous fodders [3], which plays an important role in the nutrition of grazing animals where there is less scope of conventional fodders. Oaks (Quercus spp.) are one such tree fodder which is the dominant, climax tree species of the moist temperate forests of the North Western Himalayan region (NWHR). During extreme climatic condition in this agro-climatic zone, when ruminants cannot go out to graze oak leaves take cares the nutritive requirement of such animals.

Even though the oak leaves are abundantly available in the NWHR, toxicity problems exist due to sole feeding of oak leaves in the diet of ruminants [4]. Moreover, previous workers reported oak toxicity even on feeding oak leaves partially in the diets of the

Copyright: The authors. This article is an open access article licensed under the terms of the Creative Commons Attributin License (http:// creative commons.org/licenses/by/2.0) which permits unrestricted use, distribution and reproduction in any medium, provided the work is properly cited. ruminants [5]. Quercus species are reported to contain the high levels of hydrolysable tannins (HT) which are the main reason for the toxicity in the livestock. HT undergo acid and microbial hydrolysis to release simple phenolics which there by cause toxicity $[6,7]$. Chopping of the oak leaves is the simple procedure by which the polyphenol content of the oak leaves can be reduced. Chopping helps the phenolic oxidases to get exposed with tannins which results in tannin reduction.

So, the present study was undertaken with two objectives: (i) To identify the safe inclusion level of oak leaves in replacing the conventional high quality oat fodder (OF) for feeding ruminants through Hohenheim in vitro gas production technique (IVGPT) (ii) To explore the additional benefit of chopping oak leaves on reducing the polyphenol content and on rumen metabolism through IVGPT.

\section{Materials and Methods}

Ethical approval

The study was undertaken after taking necessary approvals from the Institutional Animal Ethical Committee of the University.

\section{Sampling of the oak leaves}

The fresh mature oak (Quercus leucotrichophora) leaves were manually lopped from the nearby forest area of Palampur, Kangra District, Himachal Pradesh, India. A part of the lot was chopped by a 
mechanical chopper to a length of $2 \pm 0.5 \mathrm{~cm}$. OF were purchased from the local market. Nine different diets were prepared by mixing OF with oak leaves i.e. one diet comprising $100 \%$ OF, four diets with mixing OF with FOL $(75: 25,50: 50,25: 75$, and $0: 100)$ and another four diets with mixing OF with COL $(75: 25$, 50:50, 25:75, and 0:100).

\section{Chemical analysis}

The chemical composition of the FOL and COL, and $\mathrm{OF}$ were determined by the method of AOAC (2000) while fiber fractions were estimated as per the methods suggested by Van Soest et al. [8]. Polyphenol profile of oak leaves was estimated by the method of Makkar [9]. Total phenols (TP) and non-tannin phenols (NTP) were estimated by Folin-Ciocalteau method in combination with polyvinylpolypyrrolidone, with tannic acid as a reference standard [9]. The condensed tannins (CT) were estimated by using butanol-HCl method.

\section{Rumen liquor sampling}

Rumen liquor was collected from two rumen cannulated cattle (body weight $=220 \mathrm{~kg}$ ), strained through a four-layered muslin cloth and pooled together which was used as an inoculum source for in vitro studies. The donor animals were fed $60 \%$ wheat straw and $40 \%$ concentrate. Five different diets were prepared mixing OF with oak leaves (FOL and COL) in the ratios of 100:0, 75:25, 50:50, 25:75, and 0:100 and evaluated through Hohenheim IVGPT suggested by Menke et al. [10] with $200 \mathrm{mg}$ substrate and $30 \mathrm{ml}$ of buffered rumen liquor. All the syringes were incubated at $39^{\circ} \mathrm{C}$ for $24 \mathrm{~h}$ in buffered rumen liquor of cattle. After $24 \mathrm{~h}$, the total gas production was recorded, and the contents were analyzed for in vitro methane production, protozoal count, and ammonia-N. In vitro methane production was estimated in gas-liquid chromatography (gas chromatography [GC], Nucon 5765, Nucon Engineers, New Delhi, India) equipped with a flame ionization detector. The column was of stainless steel packed with a propak-q (length $1.8 \mathrm{~m}$; o.d $0.3 \mathrm{~mm}$; i.d $2 \mathrm{~mm}$; mesh 80-100). The analytical condition of GC was carrier gas $\mathrm{N}_{2}$ flow $40 \mathrm{ml} / \mathrm{min}$, $\mathrm{H}_{2} 30 \mathrm{ml} / \mathrm{min}$, air $300 \mathrm{ml} / \mathrm{min}$, and temperature range at injection port was $150^{\circ} \mathrm{C}$, column $60^{\circ} \mathrm{C}$, and at detector was $130^{\circ} \mathrm{C}$. The peak was compared with the standard $\left(50 \% \mathrm{CH}_{4}\right.$ and $50 \% \mathrm{CO}_{2}$ from SPANCAN calibration gas, Spantech, Surrey, UK) and the analysis and calculation used the Aimil chromatography data system (WINACDS, New Delhi, India).

Metabolizable energy (ME) values of samples were calculated by a formula derived by Menke and Steingass [11]. The microbial protein and digestibility were calculated with the $400 \mathrm{mg}$ substrate incubated in $40 \mathrm{ml}$ of buffered rumen liquor.

$\mathrm{ME}(\mathrm{MJ})=2.20+0.136^{*}$ gas $(\mathrm{ml} / 200 \mathrm{mg} \mathrm{DM})+$ $0.0057 * \mathrm{CP}+0.0029 * \mathrm{EE}$

Microbial protein was estimated by the following formula:
Microbial protein $(\mathrm{mg})=\mathrm{TD}(\mathrm{mg})-(2.25 \times$ net gas volume)

Whereas, TD $=$ True digestible matter (substrate incubated-NDF)

The in vitro gas production was completed in three runs (statistical replicates) with each sample incubated in triplicate (analytical replicates).

\section{Statistical analysis}

The analytical replicates were averaged prior to statistical analysis with each run being the statistical replicate. The data were analyzed using one-way analysis of variance procedures (SPSS base 7.5 for windows [1997]) and the difference between the treatments means were compared by Duncan's multiple range tests. Results are presented as means and standard error of means. Treatment effects or differences were considered significant if $\mathrm{p}<0.05$.

\section{Results and Discussion}

\section{Chemical composition}

The chemical composition of the oat fodder (OF) and oak leaves are presented in the Table-1. The chemical composition of OF at the early maturity was comparable to that reported by earlier workers [12-16]. The organic matter $(\mathrm{OM})$, crude protein $(\mathrm{CP})$, ether extracts (EE), nitrogen free extract (NFE), and Crude fibre $(\mathrm{CF})$ content of the $\mathrm{OF}$ was $88.4,14.7,3.66$, 46.47 , and $23.57 \%$, respectively. There was no significant difference between the values in the $\mathrm{OM}, \mathrm{CP}$, EE, NFE, and CF content between FOL and COL. The chemical composition of the oak leaves was comparable to that reported by earlier workers [17-21].

\section{Polyphenol content}

Polyphenol content (on DM basis) of the OF, and the oak leaves are presented in the Table- 2 . There was $10.1,9.43,10.3,7.0,11.1 \%$ reduction in the TP, NTP, TT, CT and HT values due to chopping of the oak leaves. There was a significant difference in the TP, NTP, TT, and HT content between the FOL and COL. The reduction of the polyphenol content of the oak leaves is due to the higher susceptibility of COL to oxidative enzymes and conversion of higher polymerization leading to inert phenols. The degree of susceptibility of HT to the oxidative enzyme is relatively more than the other polyphenol $[22,23]$.

\section{Total gas production}

The total gas production per $200 \mathrm{mg}$ substrate was higher at the $100 \%$ oat concentration $(41.17 \mathrm{ml})$. Increase in levels of oak decreased total gas production $(\mathrm{ml} / 200 \mathrm{mg} \mathrm{DM})($ Graph-1) at a decreasing rate. Gas production was more in the COL group than the FOL at the same ratio. There was a significant difference $(p<0.01)$ between the values of $25 \%$ oak leaves in COL and FOL. The gas produced in the syringes is largely due to acetate and butyrate, and lower gas production is associated with propionate production. Easily fermentable carbohydrates yield higher propionate therefore leading to less gas. The gas production 
Table-1: Chemical composition of OF and oak leaves (\% DMB).

\begin{tabular}{lcccccc}
\hline $\begin{array}{l}\text { Substrate } \\
\text { component }\end{array}$ & \multicolumn{7}{c}{ Chemical composition } \\
\cline { 2 - 7 } & CP & EE & NDF & ADF & ADL & TA \\
\hline OF & $14.70^{\mathrm{a}} \pm 0.13$ & $3.66^{\mathrm{c}} \pm 0.12$ & $61.52^{\mathrm{c}} \pm 0.11$ & $35.04^{\mathrm{c}} \pm 0.17$ & $3.33^{\mathrm{c}} \pm 0.07$ & $11.60^{\mathrm{a}} \pm 0.12$ \\
FOL & $10.45^{\mathrm{c}} \pm 0.09$ & $4.83^{\mathrm{a}} \pm 0.11$ & $66.50^{\mathrm{b}} \pm 0.12$ & $50.16^{\mathrm{b}} \pm 0.10$ & $25.43^{\mathrm{b}} \pm 0.11$ & $4.07^{\mathrm{b}} \pm 0.13$ \\
COL & $10.87^{\mathrm{b}} \pm 0.10$ & $4.37^{\mathrm{b}} \pm 0.06$ & $69.77^{\mathrm{a}} \pm 0.11$ & $52.10^{\mathrm{a}} \pm 0.18$ & $26.10^{\mathrm{a}} \pm 0.10$ & $4.33^{\mathrm{b}} \pm 0.11$ \\
\hline
\end{tabular}

* Mean of six samples each, means bearing different superscripts ( $a, b$ and $c)$ in a column differ significantly $(p<0.01)$, $\mathrm{CP}=$ Crude protein, $\mathrm{EE}=$ Ether extract, $\mathrm{NDF}=$ Neutral detergent fibre, $\mathrm{ADF}=$ Acid detergent fiber, $\mathrm{ADL}=\mathrm{Acid}$ detergent lignin, $\mathrm{TA}=$ Total ash, $\mathrm{OF}=$ Oat fodder

Table-2: Polyphenol profile of OF and oak leaves (\% DMB).

\begin{tabular}{lcccrr}
\hline $\begin{array}{l}\text { Substrate } \\
\text { component }\end{array}$ & \multicolumn{5}{c}{ Polyphenol profile } \\
\cline { 2 - 6 } & TP & NTP & TT & CT & HT \\
\hline OF & $1.20^{\mathrm{c}} \pm 0.09$ & $0.46^{\mathrm{b}} \pm 0.03$ & $0.74^{\mathrm{c}} \pm 0.01$ & $0.01^{\mathrm{c}} \pm 0.00$ & $0.73^{\mathrm{c}} \pm 0.01$ \\
FOL & $6.93^{\mathrm{a}} \pm 0.08$ & $0.53^{\mathrm{a}} \pm 0.02$ & $6.41^{\mathrm{a}} \pm 0.06$ & $1.28^{\mathrm{a}} \pm 0.02$ & $5.13^{\mathrm{a}} \pm 0.04$ \\
COL & $6.23^{\mathrm{b}} \pm 0.06$ & $0.48^{\mathrm{b}} \pm 0.01$ & $5.75^{\mathrm{b}} \pm 0.06$ & $1.19^{\mathrm{b}} \pm 0.03$ & $4.56^{\mathrm{b}} \pm 0.04$
\end{tabular}

*Mean of six samples each, means bearing different superscripts $(a, b$ and $c)$ in a column differ significantly $(p<0.01)$, $\mathrm{TP}=$ Total phenol, NTP=Non-tannin phenol, $\mathrm{TT}=$ Total tannin, $\mathrm{CT}=$ Condensed Tannin, $\mathrm{HT}=\mathrm{Hydrolysable}$ tannin, OF=Oat fodder, $\mathrm{COL}=$ Chopped oak leaves, FOL=Fresh oak leaves

is negatively related with the neutral detergent fiber (NDF) content and positively with the starch content. Tannins especially HT at higher levels are toxic to the rumen microbes, therefore, leading to less gas production [24].

\section{Methane}

The methane production was maximum in the $100 \%$ OF level $(16.9 \mathrm{ml} / 200 \mathrm{mg})$. As the concentration of oak leaves increased in the substrate, the methane production decreased (Graph-2). The effect on methane production was parallel to decreased total gas production. Even at the $25 \%$ inclusion level of oak, there were $5.2 \%$ and $21.24 \%$ reduction of methane in fresh and chopped oak, respectively. There was significant $(\mathrm{p}<0.01)$ difference between the methane produced in COL and FOL group (except at 25\% oak). There was less production of methane in COL than the FOL of the same ratio. Studies using CT-containing forages such as big trefoil (Lotus peduncalatus, $53 \mathrm{~g} / \mathrm{kg} \mathrm{CT}$ ), sulla (Hedysarum coronarium, 27-68 g/kg CT), red clover (Trifolium pretense, $3 \mathrm{~g} / \mathrm{kg} \mathrm{CT}$ ), and Sericea lespedeza (Lespedeza cuneata, $177 \mathrm{~g} / \mathrm{kg} \mathrm{CT}$ ) reported reductions in $\mathrm{CH}_{4}$ emissions [25-28]. Tannins present in different plants such as Calliandra calothyrsus [29] and Onobrychis viciifolia [30] and Populus deltoides [31] reduced methane production under in vitro conditions. Similar results were reported by Woodward et al., [26] that CT containing $H$. coronarium forage reduced methane production per kg DM intake (19.5 vs. $24.6 \mathrm{~g}$ ) in grazing cows. Similarly, sheep fed L. corniculatus silage reduced methane production [32]. Waghorn et al. [25] reported $16 \%$ reduction in methane production in lambs fed on CT containing Lotus pedunculatus (lotus).

\section{Microbial protein synthesis}

Microbial protein synthesis was estimated through equations with the help of total gas production. Microbial protein was higher at the $100 \%$ OF

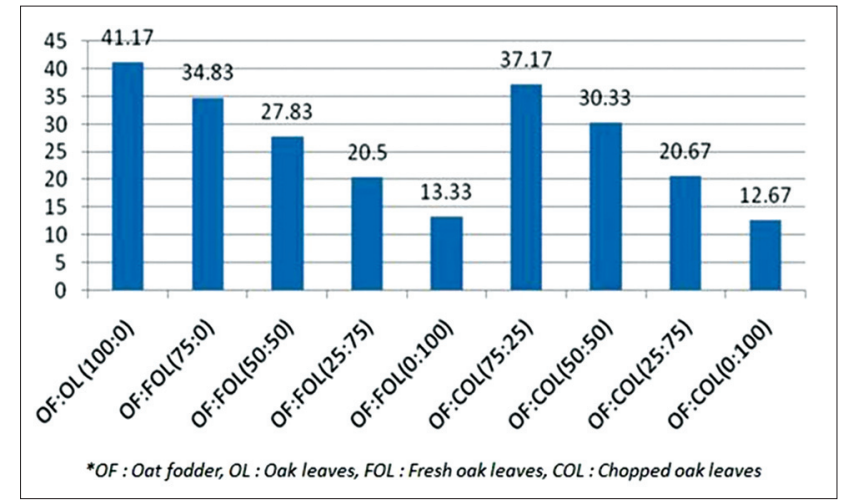

Graph-1: Total gas (ml/200 mg dry matter).

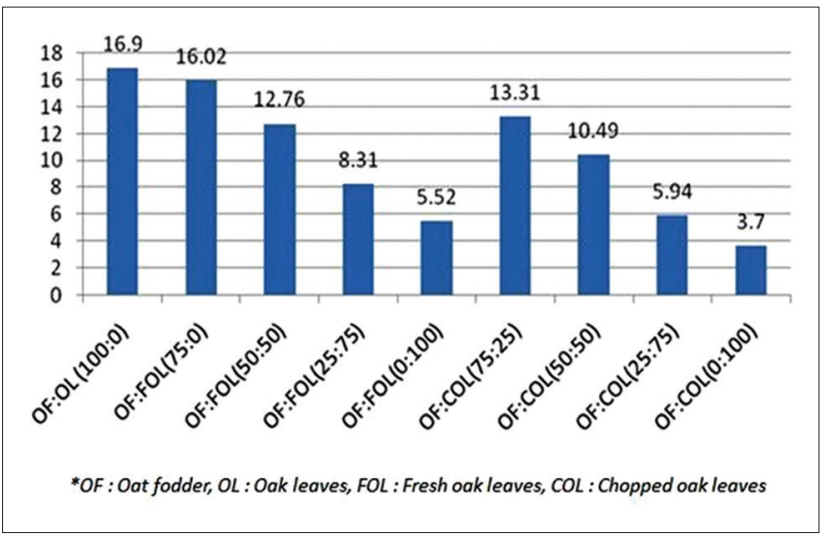

Graph-2: Methane production ( $\mathrm{ml} / 200 \mathrm{mg}$ dry matter).

(164.69 mg), however, as the oak leaves percentage increased in the substrate incubated the production of microbial protein decreased linearly. There was no significant difference between the values in COL and FOL. The linear reduction in the microbial protein was due to the toxic effect of the polyphenols to the rumen microbes [33]. For microbial protein synthesis synchronization of the rate of degradation of $\mathrm{N}$ and carbohydrate components in the rumen is important 
for efficient utilization of rumen ammonia nitrogen. Therefore, there is a reduction of microbial protein synthesis with respect to ammonia nitrogen.

\section{True dry matter (DM) and OM digestibility}

Both the DM and the OM digestibility were higher in the $100 \%$ OF ( 81.14 and $81.73 \%$, respectively). Both DM and OM digestibility followed the same trend, i.e. when the percentage oak leaves increased the digestibility decreased (Graph-3). There was a significant difference between the values at $50 \%$ oak leaves in COL and FOL. The reduction in the digestibility is attributed to the high tannin and lignin content in the diet $[34,35]$. Tannins reduce digestibility by reducing the activity of rumen microbes, by binding with rumen enzymes, or by binding with feed components [36]. Particularly in case of tree leaves, tannins are present in NDF and acid detergent fiber (ADF) fractions in certain amounts which are tightly bound to the cell wall and cell proteins and it is believed to be involved in decreasing digestibility [37].

\section{Ammonia nitrogen}

The ammonia nitrogen $(\mathrm{mg} / 30 \mathrm{ml})$ in the different dietary combination is presented in Table- 3 . The ammonia nitrogen $(\mathrm{mg} / 30 \mathrm{ml})$ produced was maximum in the $100 \%$ OF (6.6). There was a significant

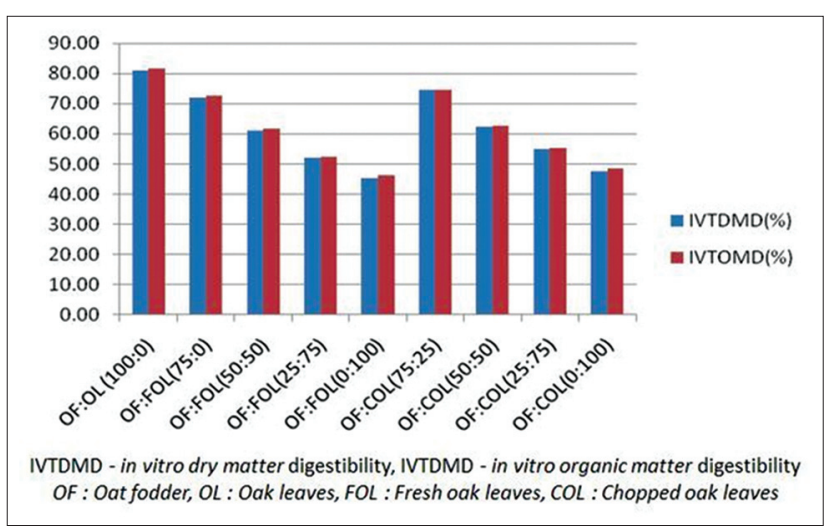

Graph-3: Effect of replacing oat fodder with fresh or chopped oak leaves on in vitro digestibility. difference $(p<0.01)$ in the ammonia nitrogen production in all the ratios between COL and FOL groups (except at 25\%). Tannins are known to bind with proteins, which is the key reason for the reduction of rumen ammonia concentration [38]. Many authors have indicated that the principal effects of tannins in ruminal fermentation include a reduction in proteolysis of dietary protein and subsequently lower concentrations of ammonia in rumen fluid $[39,40]$. All ammonia concentrations were higher than the $100 \mathrm{mg} / \mathrm{L}$ reported by Van Soest et al. [8] as optimal for the efficiency of amino acid synthesis and microbial growth. Although that value might depend on a number of factors, such as the amount of available fermentable energy [41], ammonia concentrations were probably adequate for optimal rumen fermentation in all cases.

\section{Protozoal count}

The number of protozoa in the different ratio of oat: Oak is represented in the Table-3. The polyphenol content of the substrate did not show any significant difference on the protozoal count. Similar results were reported with $Q$. leucotrichophora [20]. Tavendale et al. [42] suggested that inhibition of growth of methanogens is due to the bacteriostatic and bactericidal effects of CT. Since some of the methanogens are ecto- and endo-symbiotically associated with protozoa, a reduction in methanogens would probably affect the protozoal population [43]. The effects of tannin on the protozoal number are conflicting, some authors claim in the reduction of protozoal number with tannin supplementation, but others claim no effect. Monforte-Briceno et al. [44] studied the defaunating properties of 15 tree fodders containing tannins, but the inhibitory effect on protozoa was observed in Acacia farnesiana, C. calothyrsus and Lysiloma latisiliquum. Tannins present in tanniferous plants are not equally efficient in reducing the protozoal count.

\section{ME values}

The calculated ME (MJ/kg DM) values were higher in the $100 \%$ OF group (7.9). A similar trend

Table-3: Effect of OF and oak leaves at various combinations on in vitro gas production and rumen fermentation.

\begin{tabular}{|c|c|c|c|c|c|}
\hline Combination & $\begin{array}{c}\text { Microbial } \\
\text { protein (mg) }\end{array}$ & $\begin{array}{c}\text { Ammonia nitrogen } \\
(\mathrm{mg} / 30 \mathrm{ml})\end{array}$ & $\begin{array}{l}\text { Protozoa } \\
\left(\times 10^{4}\right) / \mathrm{ml}\end{array}$ & $\begin{array}{c}\text { ME } \\
(M J / k g ~ D M)\end{array}$ & $\begin{array}{l}\text { Methane } \\
\mathrm{ml} / 200 \mathrm{mg}\end{array}$ \\
\hline Oat (100\%) & $164.69^{a}$ & $6.60^{a}$ & $1.74^{\mathrm{ab}}$ & $7.89^{a}$ & $16.90^{a}$ \\
\hline \multicolumn{6}{|l|}{$\mathrm{OF}+\mathrm{FOL}$} \\
\hline Oat $(75 \%)+$ oak $(25 \%)$ & $155.22^{\mathrm{ab}}$ & $6.20^{\mathrm{b}}$ & $1.85^{\mathrm{ab}}$ & $7.03^{c}$ & $16.02^{\mathrm{a}}$ \\
\hline Oat $(50 \%)+$ oak $(50 \%)$ & $143.37^{\mathrm{bc}}$ & $5.13^{e}$ & $2.37^{a}$ & $6.07^{e}$ & $12.76^{b}$ \\
\hline Oat $(25 \%)+$ oak $(75 \%)$ & $133.06^{c}$ & $5.23^{\mathrm{de}}$ & $2.11^{\mathrm{a}}$ & $5.07^{f}$ & $8.31^{d}$ \\
\hline Oat $(0 \%)+$ oak $(100 \%)$ & $133.14^{c}$ & $5.23^{\mathrm{de}}$ & $1.56^{\mathrm{ab}}$ & 4.099 & $5.52^{e}$ \\
\hline \multicolumn{6}{|l|}{$\mathrm{OF}+\mathrm{COL}$} \\
\hline Oat $(75 \%)+$ oak $(25 \%)$ & $156.19^{a b}$ & $5.60^{c}$ & $1.59^{\mathrm{ab}}$ & $7.34^{\mathrm{b}}$ & $13.31^{b}$ \\
\hline Oat $(50 \%)+$ oak $(50 \%)$ & $138.83^{c}$ & $5.47^{\mathrm{cd}}$ & $1.89^{a b}$ & $6.41^{d}$ & $10.49^{c}$ \\
\hline Oat $(25 \%)+$ oak $(75 \%)$ & $144.30^{\mathrm{bc}}$ & $5.10^{\mathrm{e}}$ & $2.18^{a}$ & $5.09^{f}$ & $5.94^{\mathrm{e}}$ \\
\hline Oat $(0 \%)+$ oak $(100 \%)$ & $144.40^{\mathrm{bc}}$ & $4.70^{f}$ & $1.22^{\mathrm{a}}$ & $4.00^{g}$ & $3.70^{e}$ \\
\hline SEM & 2.36 & 0.11 & 0.10 & 0.26 & 0.90 \\
\hline p significance & $p<0.01$ & $p<0.01$ & NS & $\mathrm{p}<0.01$ & $p<0.01$ \\
\hline
\end{tabular}

* Mean of six samples each, Means bearing different superscripts ( $a, b, c, d, e, f$ and $g$ ) in a column differ significantly $(p<0.01), O F=O a t$ fodder, $S E M=S t a n d a r d$ error of means, $D M=$ Dry matter, $C O L=C h o p p e d ~ o a k$ leaves, $\mathrm{FOL}=$ Fresh oak leaves, ME=Metabolizable energy 
was seen as that of the gas production in oak groups, i.e. as the \% oak increased in the substrate, the ME values decreased. The ME values of the fresh oak group was 7, 6.1, 5.07 and $4.09 \mathrm{MJ} / \mathrm{kg} \mathrm{DM}$ and in chopped oak group was 7.34, 6.41, 5.09 and $4 \mathrm{MJ} / \mathrm{kg}$ $\mathrm{DM}$ at $25,50,75$ and $100 \%$ respectively. The ME values of $100 \%$ FOL and COL were also estimated by Ajith [20], ME value of FOL and COL reported by him were 5.76 and $5.52 \mathrm{MJ} / \mathrm{kg} \mathrm{DM}$. It is well-known fact that NDF, ADF and CT are negatively associated with ME of feedstuffs [45].

\section{Conclusion}

The current in vitro study revealed that the addition of oak leaves reduced the methane production and ammonia nitrogen levels; however, it also decreased the OM digestibility, microbial protein synthesis and ME values linearly. Oak tannins didn't have any effect on the protozoal number. Even though, there was a reduction in polyphenol content due to chopping, it was effective only at lower inclusion levels (i.e. $25 \%$ and $50 \%$ ). However, comprehensive in vivo studies with animal hosts need to be undertaken to evaluate the sustainability of oak leaves supplementation to mitigate rumen methanogenesis without detrimental effects on the animal as a whole.

\section{Authors' Contributions}

$\mathrm{RB}$ and $\mathrm{AK}$ planned and supervised the entire research work. KR and RJ carried out the experimental work and laboratory analysis. BS and GM prepared the manuscript along with data analysis. All authors read and approved the final manuscript.

\section{Acknowledgments}

The authors are thankful to the Indian Veterinary Research Institute, Regional Station, Himachal Pradesh, India for financial support to carry out this study.

\section{Competing Interests}

The authors declare that they have no competing interests.

\section{References}

1. Raghuvansi, S.K.S., Prasad, R., Mishra, A.S., Chaturvedi, O.H., Tripathi, M.K., Misra, A.K., Saraswat, B.L. and Jakhmola, R.C. (2007) Effect of inclusion of tree leaves in feed on nutrient utilization and rumen fermentation in sheep. Biores. Technol., 98: 511-517.

2. Kamalak, A., Canbolat, Y., Gurbuz, O., Ozay, C., Ozkan O. and Sakarya, M. (2004) Chemical composition and in vitro gas production characteristics of several tannin containing tree leaves. Livest. Res. Rural Dev., 16(6): 44.

3. Akram, M., Hanjra, S.H., Qazi, M.A. and Bhatti, J.A. (1990) Availability and use of shrub and tree fodder in Pakistan. Proceedings: Workshop, Denpasar, Indonesia 24-29 July, 1989. IDRC, Ottawa, Canada.

4. Bhar, R., Sharma, R., Ajith, M.K., Kannan, A., Singh, B. and Bhat, T.K. (2013) Chronic toxicity in gaddi goats fed on Quercus leucotrichophora leaves as sole feed. VSA, Subsection: Veterinary Sciences and Animal Husbandry, Section of Animal, Veterinary and Fisheries Sciences,
Proceeding. 100th Indian Science Congress, Kolkata, January 3-7, 2013, Calcutta University, Kolkata, India. p49.

5. Lohan, O.P., Lall, D., Vaid, J. and Negi, S.S. (1983) Utilization of oak tree (Quercus incana) fodder in cattle rations and fate of oak-leaf tannins in the ruminant system. Indian J. Anim. Sci., 53(10): 1057-1063.

6. Murdiati, T.B., McSweeney, C.S. and Lowry, J.B. (1992) Metabolism in sheep of gallic acid, tannic acid and hydrolysable tannin from Terminalia oblongata. Aust. J. Agric. Res., 436: 1307-1319.

7. Huang, X.D., Liang, J.B., Tan, H.Y., Yahya, R., Khamseekhiew, B. and Ho, Y.W. (2010) Molecular weight and protein binding affinity of Leucaena condensed tannins and their effects on in vitro fermentation parameters. Anim. Feed Sci. Technol., 159: 81-87.

8. Van Soest, P.J., Robertson, J.B. and Lewi, B.A. (1991) Methods for dietary fibre, neutral detergent fibre and nonstarch polysaccharides in relation to animal nutrition. $J$. Dairy Sci., 74: 3853-3597.

9. Makkar, H.P.S. (2003) Quantification of Tannins in Tree and Shrub Foliage. A Laboratory Manual. International Academic Energy Agency, Kluwer Academic Publishers, Dordrecht, Netherlands.

10. Menke, K.H., Raab, L., Salewski, A., Steingass, H., Fritz, D. and Schneider, W. (1979) The estimation of the digestibility and metabolizable energy content of ruminant feeding stuffs from the gas production when they are incubated with rumen liquor in vitro. J. Agric. Sci., 93: 217-222.

11. Menke, K.H. and Steingass, H. (1988) Estimation of energetic feed value obtained chemical analysis and gas production using rumen fluid. Anim. Res. Dev., 28: 7-55.

12. McCartney, D. and Vaage, A. (1994) Comparative yield and feeding value of barley, oat and triticale silages. Can. J. Anim. Sci., 74: 91-96.

13. Ashraf, Y. (1996) Study on chemical composition of different varieties of indigenous fodders as influenced by different stages of growth. Thesis Ph.D. Institute of Chemistry, University of the Punjab, Lahore, India.

14. Khan, M.A., Sarwar, M., Nisa, M., Iqbal, Z., Khan, M.S., Lee, W.S., Lee, H.J. and Kim, H.S. (2006) Chemical composition, in situ digestion kinetics and feeding value of oat grass (Avena sativa) ensiled with molasses for Nili-Ravi buffaloes. Asian Aust. J. Anim. Sci., 19: 1127-1133.

15. Ammar, H., Lopez, S. and Andres, S. (2010) Influence of maturity stage of forage grasses and leguminous on their chemical composition and in vitro dry matter digestibility. Options Mediterr. Ser. A., 92: 199-203.

16. Hedhly, T., Miladi, D., Rekik, B. and Bergaoui, R. (2011) Effect of integration of Avena sativa L. and Trifolium alexandrinum $\mathrm{L}$. in the ration on milk production performance of rabbit does. Res. Opin. Anim. Vet. Sci., 1: 245-249.

17. Devarajan, S. (1999) Effect of tannins on the ruminal degradation kinetics of locally available tree forages. Thesis, M.V.Sc, Deemed University, Indian Veterinary Research Institute, Deemed University, Izatnagar, India.

18. Paswan, V.K. and Sahoo, A. (2010) Feeding of oak (Quercus leucotrichophora) leaves and evaluation for its potential inclusion in the feeding of native heifers of kumaon Himalaya. Trop. Anim. Health Prod., 44: 1931-1938.

19. Bharatbhushan, M. (2012) Studies on some locally available tree leaves and there system of feeding in gaddi goats. Thesis M.V.Sc. Deemed University, Indian Veterinary Research Institute, Izatnagar, India. p59-64.

20. Ajith, M.K. (2012) Studies on detannification of oak (Quercus leucotrichophora) leaves for development of feeding system for gaddi goats. M.V.Sc Thesis, Indian Veterinary Research Institute, Deemed University. Izatnagar, UP, India.

21. Ambi, S. (2013) Effect of processing on polyphenol content, antioxidant activity and nutrient utilization of Oak (Quercus leucotrichophora) leaves in gaddi goat. M.V.Sc Thesis, Indian Veterinary Research Institute, Deemed University. Izatnagar, UP, India. 
22. Haslam, E. (1966) Chemistry of Vegetable Tannins. Academic Press, London and New York.

23. Bagheripour, E., Rouzbehan, Y. and Alipour, D. (2008) Effect of ensiling, air-drying and addition of polyethylene glycol on in vitro gas production of pistachio by-products. Anim. Feed Sci. Technol., 146: 327-336.

24. Sallam, S.M.A., da Silve Bueno, I.C., Godoy, P.B., Nozella, E.F., Vitti, D.M.S. and Abdalla, A.L. (2010) Ruminal fermentation and tannins bioactivity of some browses using a semi-automated gas production technique. Trop. Subtrop. Agroecosys., 12: 1.

25. Waghorn, G.C., Tavendale, M.H. and Woodfield, D.R. (2002) Methanogenesis in forages fed to sheep. Proc. N.Z. Grass. Assoc., 64: 167-171.

26. Woodward, S.L., Waghorn, G.C., Lassey, K.R. and Laboyrie, P.G. (2002) Does feeding sulla (Hedysarum coronarium) reduce methane emissions from dairy cows. Proc. N.Z. Soc. Anim. Prod., 62: 227-230.

27. Woodward, S.L., Waghorn, G.C. and Laboyrie, P.G. (2004) Condensed tannins in birdsfoot trefoil (Lotus corniculatus) reduce methane emissions from dairy cows. Proc. N.Z. Soc. Anim. Prod., 64: 160-164.

28. Pinares-Patino, C.S., Ulyatt, M.J., Waghorn, G.C., Lassey, K.R., Barry, T.N., Holmes, C.W. and Johnson, D.E. (2003) Methane emission by alpaca and sheep fed on lucerne hay or grazed on pastures of perennial ryegrass/white clover or birdsfoot trefoil. J. Agric. Sci., 140: 215-226.

29. Hess, H.D., Kreuzer, M., Diaz, T.E., Lascano, C.E., Carulla, J.E. and Solvia, C.R. (2003) Saponin rich tropical fruits affect fermentation and methanogenesis in faunated and defaunated fluid. Anim. Feed Sci. Technol., 109: 79-94.

30. McMahon, L.R., Majak, W., McAllister, T.A., Hall, J.W., Jones, G.A., Popp, J.D. and Cheng, K.J. (1999) Effect of sainfoin on in vitro digestion of fresh alfalfa and bloat in steers. Can. J. Anim. Sci., 79: 203-212.

31. Patra, A.K., Kamra, D.N. and Agarwal, N. (2008) Effect of extracts of leaves on rumen methanogenesis, enzyme activities and fermentation in in vitro gas production test. Indian J. Anim. Sci., 78: 91-96.

32. Woodward, S.L., Waghorn, G.C., Ulyatt, M.J. and Lassey, K.R. (2001) Early indication that feeding lotus will reduce methane emission from ruminants. Proc. N.Z. Soc. Anim. Prod., 61: 23-26.

33. Patra, A.K., Saxena, J. (2009) Dietary phytochemicals as rumen modifiers: A review of the effects on microbial populations. Antonie van Leeuwenhoek, 96: 363-375.

34. Mangan, J.L. (1988) Nutritional effects of tannins in animal feeds. Nutr. Res. Rev., 1: 209-231.
35. Hagerman, A.E., Robbins, C.T., Weerasuriya, Y., Wilson, T.C. and McArthur, C. (1992) Tannin chemistry in relation to digestion. J. Range Manage., 45: 57-62.

36. Theodoridou, K., Aufrere, J., Niderkorn, V., Andueza, D., Le Morvan, A., Picard, F. and Baumont, R. (2011) In vitro study of the effects of condensed tannins in sanfoins on the digestive process in the rumen at two vegetation cycles. Anim. Feed Sci. Technol., 170: 147-159.

37. Reed, J.D., Soller, H. and Wood, A. (1990) Fodder tree and straw diets for sheep: Intake, growth, digestibility and the effect of phenolics on nitrogen utilization. Anim. Feed Sci. Technol., 30: 39-50.

38. Szumacher-Strabel, M. and Cieslak, A. (2012) Dietary possibilities to mitigate rumen methane and ammonia production. In: Liu, G., editor. Greenhouse Gases Capturing, Utilization and Reduction. Intech, Rijeka, Croatia.

39. Frutos, P., Hervas, G., Giraldez, F.J. and Mantecon, A.R. (2004) An in vitro study on the ability of polyethylene glycol to inhibit the effect of quebracho tannins and tannic acid on rumen fermentation in sheep, goats, cows and deer. Aust. J. Agric. Res., 55: 1125-1132.

40. Mueller-Harvey, I. (2006) Unravelling the conundrum of tannins in animal nutrition and health. J. Sci. Food Agric., 86: 2010-2037.

41. Huntington, G.B. and Archibeque, S.L. (2000) Practical aspects of urea and ammonia metabolism in ruminants. Proc. Am. Soc. Anim. Sci., 1999.

42. Tavendale, M.H., Meagher, L.P., Pacheco, D., Walker, N., Attwood, G.T. and Sivakumaran, S. (2005) Methane production from in vitro rumen incubations with Lotus pedunculatus and Medicago sativa, and effects of extractable condensed tannin fractions on methanogenesis. Anim. Feed Sci. Technol., 123: 403-419.

43. Tan, H.Y., Sieo, C.C., Abdullah, N., Liang, J.B., Huang, X.D. and Ho, Y.W. (2011) Effects of condensed tannins from Leucaena on methane production, rumen fermentation and populations of methanogens and protozoa in vitro. Anim. Feed Sci. Technol., 169: 185-193.

44. Monforte-Briceno, G.E., Sandoval-Castro, C.A., RamirezAviles, L. and Capetillo-Leal, C.M. (2005) Defaunating capacity of tropical fodder trees: Effects of polyethylene glycol and its relationship to in vitro gas production. Anim. Feed Sci. Technol., 123-124: 313-327.

45. Kamalak, A., Atalay, A.I., Ozkan, C.O., Kaya, K. and Tatliyer, A. (2011) Determination of nutritive value of Trigonella kotschi Fenz hay harvested at three different maturity stages. Kafkas Univ. Vet. Fak. Derg., 17: 635-640. 